\title{
THE ECONOMIC ASSESMENT OF PRODUCTION TECHNOLOGY OF HARD WHEAT DEPENDING ON THE PRODUCTION INTENSITY LEVEL
}

\author{
Alicja Sulek ${ }^{1}$, Assoc. Prof. Marta Wyzinska ${ }^{1}$, Dr. Eng. \\ ${ }^{1}$ Institute of Soil Science and Plant Cultivation - State Research Institute, 8 Czartoryskich St., 24-100 Pulawy, Poland
}

\begin{abstract}
The aim of the study was to assess the production and economic effects of spring wheat cultivar SMH87 depending on the intensity of production technology. The analysis was based on research conducted in 2013-2014 at the Experimental Station in Osiny belonging to the Institute of Soil Science and Plant Cultivation - State Research Institute in Pulawy. Wheat was grown using the following production technologies: medium-intensive and intensive. The studied technologies differed in the level of mineral fertilization and chemical plant protection against weeds, diseases, and pests. The studies showed a significant influence of the production technology intensity level on durum wheat yielding. Durum wheat cultivated under intensive technology yielded higher than under the average level of agrotechnics. However, a significant increase in grain yield was observed in the harvest year 2014, amounting to 1,07 t.ha-1. The lowest direct costs were incurred with the use of medium-intensive technology, while the highest in intensive technology conditions. The difference in direct costs resulted primarily from the reduction of consumption of mineral fertilizers and reduction of plant protection treatments under the integrated technology compared to the intensive technology. The highest direct surplus from 1 ha of durum wheat cultivation was obtained with the use of intensive technology in 2014 (PLN 3696 ), which was $18.7 \%$ higher than the average intensive technology. The profitability of durum wheat production in every technology was high. The most favourable direct profitability index was obtained by durum wheat cultivated according to medium-intensive technology.
\end{abstract}

Key words: durum wheat, production technology, economic assessment, yield.

JEL code: Q10, Q14

\section{Introduction}

Durum wheat (Triticum durum) is a species cultivated in regions with warm climates and low rainfall (Asia, Middle East, North America, Australia and Africa). Compared to common wheat, grains of durum wheat are characterized by vitreous, hard endosperm with a higher protein content, including gluten proteins, with a higher content of carotenoid dyes and a lighter and thinner fruit and seed coat (Rachon L., at all., 2015). Due to these properties, durum wheat grain reaches a high price and is a sought-after raw material on the international market, mainly for the production of pasta. Interest in durum wheat cultivation is growing not only in traditional regions, but mainly in countries where durum wheat had not been cultivated or had been marginally cultivated, e.g. Hungary, Germany or Poland (Rachon L., Szumilo G., 2002; 2006; Segit Z., Szwed-Urbas K., 2000). Due to the unique technological value of grain and its use in production, it is important to develop a production technology that would ensure its profitability. The profitability of cereal production is determined by grain purchase prices and the level of intensity of production technology, measured by direct costs, which reflect the consumption of means of production. One of the most important factors that determine the effectiveness of a given technology is mineral fertilisation, especially nitrogen fertilisation. This is the main factor influencing wheat yields. Among the factors differentiating the effectiveness of a given cereal production technology, one should mention the costs related to the protection of plants against weed infestation, diseases and insecticides (JaczewskaKalicka A., Krasinski, T., 2010). The ultimate goal of any technology to be used in practice is economic evaluation (Krasowicz S., Nowacki W., 2005). Only direct costs can be taken into account in the economic assessment, based on an incomplete, simplified calculation (Harasim A., 2007; Krasowicz S., 1999). The consequence of limiting the assessment to the direct costs is to calculate the direct surplus as the difference between the value of the grain harvested per hectare and the direct costs of the industrial means of production.

\footnotetext{
${ }^{1}$ Contacts to be added to the author, as a footnote at the bottom of the first page ( 6 point Verdana font)
} 
The analysis was based on research conducted in 2013-2014 at the Experimental Station in Osiny belonging to the Institute of Soil Science and Plant Cultivation - State Research Institute in Pulawy. Spring wheat (Triticum durum) SMH87 cultivar was cultivated in a long-term experiment with the share of $75 \%$ of cereals in crop rotation, using production technologies: medium-intensive and intensive. The studied technologies differed in terms of the level of mineral and chemical fertilization of plant protection against weeds, diseases, pests, and deforestation (Table 1). Wheat was cultivated on plots of $51 \mathrm{~m}^{2}$. In the evaluation of economic efficiency, indicators were calculated for 1 ha.

Table 1

Characterization of the applied technologies for spring wheat

\begin{tabular}{|c|c|c|}
\hline \multirow{2}{*}{ Specification } & \multicolumn{2}{|c|}{ Technologies } \\
\hline & Medium-intensive & Intensive \\
\hline Previous crop & \multicolumn{2}{|c|}{ winter rape } \\
\hline $\begin{array}{l}\text { Fertilization } \\
\left(\mathrm{kg}^{-1} \mathrm{a}^{-1}\right) \\
\mathrm{N}(\text { ammonium } \\
\text { nitrate) }\end{array}$ & $\begin{array}{c}50 \text { (in spring before sowing) } \\
40 \text { (at } \mathrm{BBCH} 31) \\
10(\text { at } \mathrm{BBCH} 51)\end{array}$ & $\begin{array}{c}60 \text { (in spring before sowing) } \\
60 \text { (at } \mathrm{BBCH} 31) \\
35(\text { at } \mathrm{BBCH} 51)\end{array}$ \\
\hline $\begin{array}{l}\text { P (superphosphate) } \\
\text { K (potassium salt) }\end{array}$ & $\begin{array}{l}70 \mathrm{P}_{2} \mathrm{O}_{5} \\
105 \mathrm{~K}_{2} \mathrm{O}\end{array}$ & $\begin{array}{l}80 \mathrm{P}_{2} \mathrm{O}_{5} \\
120 \mathrm{~K}_{2} \mathrm{O}\end{array}$ \\
\hline Herbicide & $\begin{array}{c}\text { At BBCH 31: florasulan, } \\
\text { aminopyralid } 2.4\left(0.8 \text { l.ha }{ }^{-1}\right)\end{array}$ & $\begin{array}{c}\text { At BBCH 31: florasulan, } \\
\text { aminopyralid } 2.4\left(0.81 \cdot \text { ha }^{-1}\right)\end{array}$ \\
\hline Fungicide & $\begin{array}{c}\text { At BBCH 57: azoksystrobin } \\
\left(0.6 \mathrm{l}^{\left.-\mathrm{ha}^{-1}\right)}\right.\end{array}$ & $\begin{array}{l}\text { At BBCH 41: protiokonazol, } \\
\text { spiroksamin }\left(1.0 \mathrm{l} \cdot \mathrm{ha}^{-1}\right) \\
\text { BBCH 57: azoksystrobin }+ \\
\text { propikonazol cyprokonazol } \\
\left(0.6 \mathrm{l} \cdot \mathrm{ha}^{-1}+0.4 \mathrm{l} \cdot \mathrm{ha}^{-1}\right)\end{array}$ \\
\hline Growth regulator & - & $\begin{array}{c}\text { At BBCH 31: trineksapak etylu } \\
\left(0.41 \cdot \mathrm{ha}^{-1}\right)\end{array}$ \\
\hline Insecticide & $\begin{array}{l}\text { At BBCH 51: zeta- } \\
\text { cypermetryn }\left(0.1 \mathrm{l} \cdot \mathrm{ha}^{-1}\right)\end{array}$ & $\begin{array}{l}\text { At BBCH 51: zeta- } \\
\text { cypermetryn }\left(0.1 \mathrm{l} \cdot \mathrm{ha}^{-1}\right)\end{array}$ \\
\hline
\end{tabular}

The amount of inputs was established on the basis of the actual use of fertilisers, seeds, and plant protection products in the experiment. The costs of means of production were determined on the basis of purchase prices, and the value of winter wheat production was determined according to the average grain purchase price in 2018 (IERiGZ-PIB, 2018). In grain production calculations, the sale price of PLN 1245 per $1 \mathrm{t}$ of pasta wheat grain in the fourth quarter of 2018, was assumed. In order to evaluate the studied durum wheat production technologies, the Gross Margin category was used. The direct surplus from the activity (in this case of durum wheat cultivation) according to the methodology of the European Union (EU), is the annual production value obtained from 1 ha of cultivation, lowered by the direct costs incurred to generate this production (Nowak A., et al., 2013). The final stage of the economic calculation was the calculation of the direct profitability index as the ratio of production value to direct costs. For each technology, the size of production balancing the direct costs expressed in terms of grain necessary to cover these costs, was calculated. The analysis of profitability was incomplete as the category of direct surplus did not take into account indirect costs incurred during the production process.

Average air temperatures and total precipitation during the study period were prepared on the basis of data recorded at a meteorological station in Osiny. Meteorological conditions in 2013 and 2014 are shown in Figure 1. 
Analyses of weather conditions in the wheat growing season, showed that 2013 was characterized by a lower amount of precipitation from April to July $(327.4 \mathrm{~mm})$ compared to $2014(428 \mathrm{~mm})$. Total precipitation was higher by 85 and $186 \mathrm{~mm}$, respectively, as compared to the long-term average. The year of 2013 was exceptionally warm and moderately humid, while 2014 can be described as very wet with a moderate temperature from April to June. In this year, high air temperatures occurred in July during the ripening period of the grain.

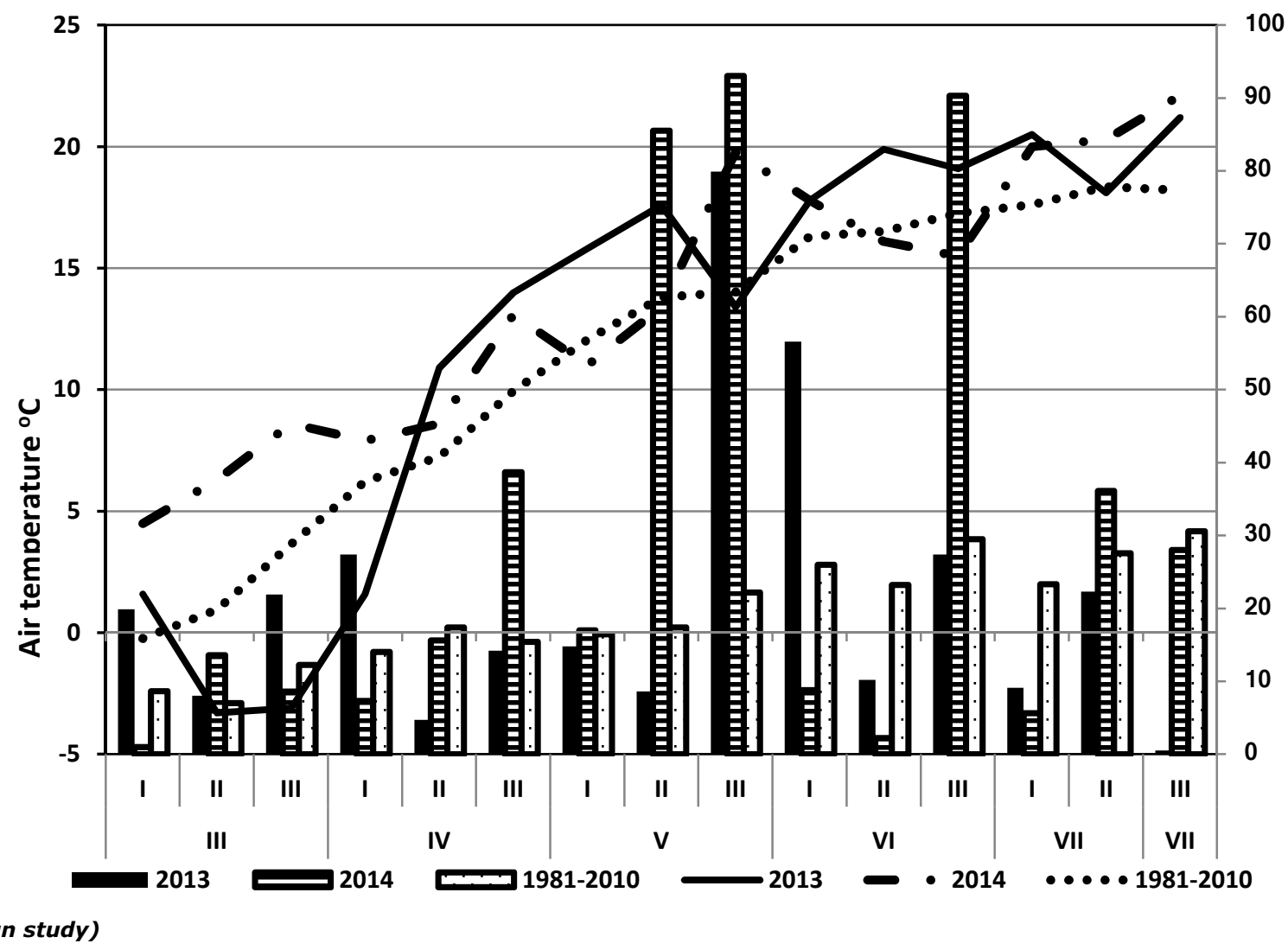

Fig. 1. Meteorological conditions in 2013 and 2014 compared to the long-term average of 1981-2010

The aim of the study was to assess the production and economic effects of spring wheat cultivar SMH87 depending on the intensity of production technology.

The results were statistically analysed using a one-way ANOVA, using the Statgraphics Centurion XVI computer program. Significance of differences between means were evaluated using the Tukey test at the level of significance $p=0.05$.

\section{Research results and discussion}

Spring durum wheat was cultivated using two production technologies, differing in mineral fertilisation and the use of chemical plant protection agents. The range of differences between production technologies is presented in Tables 1 - 2. In direct costs, mineral fertilizers and plant protection products accounted for $60.0 \%$ in medium-intensive technology, and $70.0 \%$ in intensive technology (Table 3 ). The share of seed costs in the medium-intensive technology was $39.9 \%$, while in the intensive technology $30 . \%$. Differences in the level of direct outlays determined the profitability of durum wheat production. Mineral fertilisation is the most energy-consuming and cost-consuming element of agro-technology and may exceed even $60 \%$ of outlays incurred in cereal production (Dropka D., 2004). The influence of production technology intensity on spring wheat yield depended on the year of research (Table 2). In 2013 No significant influence on durum wheat yield was found. On the other hand, in 2014 durum wheat obtained a significantly higher yield level when cultivated under intensive technology. The increase in grain yield was $1.07 \mathrm{t} \cdot \mathrm{ha}^{-1}$ in relation 
to the yield obtained under medium-intensive technology. Rachon L., at al., (2014) and Panasiewicz K., at al., (2011). They also found that durum wheat responds with a significant increase in grain yield to a higher level of agrotechnology. Jarecki W., et al. (2013) obtained a higher level of durum wheat yield after the application of $150 \mathrm{t} \cdot \mathrm{ha}^{-1}$ in the uptake up to $90 \mathrm{~N} \cdot \mathrm{ha}^{-1}$. Sulek A., Podolska G., (2012) showed that spring wheat cultivated according to intensive technology yielded $15.6 \%$ higher in comparison to the integrated technology.

The effectiveness of mineral fertilization depended on the applied production technology. Wheat grain production per $1 \mathrm{~kg}$ of nitrogen applied in mineral fertilizers, was higher under medium-intensive than under intensive technology. Taking into account all fertiliser components, the differences between mediumintensive and intensive technology in terms of productivity of $1 \mathrm{~kg} \mathrm{NPK}$ amounted to $8.2 \%$ (Table 4).

The direct surplus, which is the difference between the value of grain yield and direct costs calculated for individual production technologies, showed significant differences. A comparison of the data in Table 4 shows that higher direct costs were incurred using intensive technology. The difference in direct costs resulted primarily from the reduction of mineral fertilizers and reduction of plant protection treatments in the medium-intensity technology compared to those applied in the intensive technology. The highest direct surplus from 1 ha of durum wheat cultivation was obtained in 2014 using intensive technology (3696 PLN). It was $18.8 \%$ higher than the average intensive technology.

In 2013, the intensity of production technology did not differentiate this indicator. In other studies concerning winter wheat, a higher direct surplus from 1 ha of cultivation using intensive technology (PLN 3679) was found, which was $16.0 \%$ higher than that obtained in the integrated technology and $8.8 \%$ higher in the economical one (Sulek A., et al., 2016). On the other hand, the research by Nierobca P., et al., (2008) showed that the level of cereal yields was not proportional to the level of direct surplus. The highest direct surplus was obtained by these researchers with the use of medium-intensive and economical technology, and the lowest in the intensive technology conditions. An important measure of technology evaluation is the profitability of production, which is the relation of production value to direct costs. The profitability of spring wheat production in comparable technologies was high. In our research, the highest value of this indicator was achieved in medium-intensive technology (270\%) (Table 4). Szmigiel A., et al. (2006) also achieved the highest profitability of wheat production in low-cost technology without the use of chemical plant protection. Research conducted by Grabinski J., (2015) indicates that the profitability of the technology of lower intensity (with lower use of mineral fertilizers) was higher in relation to the technology obtained in intensive technology, despite similar wheat yields under both technologies.

Table 2

The cost of seeds, mineral fertilizers and plant protection agents (prices as at 2018)

\begin{tabular}{|c|c|c|c|c|c|c|}
\hline \multirow[b]{2}{*}{$\begin{array}{l}\text { Production } \\
\text { technology }\end{array}$} & \multicolumn{2}{|c|}{ Seeds } & \multicolumn{2}{|c|}{ Mineral fertilizers } & \multicolumn{2}{|c|}{$\begin{array}{c}\text { Plant protection } \\
\text { agents }\end{array}$} \\
\hline & PLN'ha-1 & $\begin{array}{l}\text { \% of } \\
\text { direct } \\
\text { cost }\end{array}$ & PLN'ha-1 & $\begin{array}{c}\text { \% of } \\
\text { direct } \\
\text { cost }\end{array}$ & PLN'ha-1 & $\begin{array}{c}\% \text { of } \\
\text { direct } \\
\text { cost }\end{array}$ \\
\hline $\begin{array}{l}\text { Medium- } \\
\text { intensive }\end{array}$ & 770 & 39.9 & 936 & 48.5 & 221 & 11.5 \\
\hline Intensive & 770 & 30.0 & 1275 & 49.7 & 521 & 20.3 \\
\hline
\end{tabular}




\section{Grain yields ( $\left.t \cdot \mathrm{ha}^{-1}\right)$ of durum wheat SMH87 depending on the production} technology in 2013 and 2014.

\begin{tabular}{|l|c|c|}
\hline \multirow{2}{*}{ Production technology } & \multicolumn{2}{|c|}{ Years } \\
\cline { 2 - 3 } & $\mathbf{2 0 1 3}$ & $\mathbf{2 0 1 4}$ \\
\hline Medium-intensive & 4.18 & 3.96 \\
\hline Intensive & 4.64 & 5.03 \\
\hline LSD 0.05 & n.s. & 0.825 \\
\hline
\end{tabular}

n.s. - not significant differences

(Oun study)

Yields and chosen and indicators of economic efficiency of durum wheat SMH87 production

\begin{tabular}{|c|c|c|c|c|}
\hline \multirow{4}{*}{ Specification } & \multicolumn{4}{|c|}{ Production technology } \\
\hline & \multicolumn{4}{|c|}{ Years } \\
\hline & \multicolumn{2}{|c|}{2013} & \multicolumn{2}{|c|}{2014} \\
\hline & $\begin{array}{l}\text { Medium- } \\
\text { intensive }\end{array}$ & Intensive & $\begin{array}{l}\text { Medium- } \\
\text { intensive }\end{array}$ & Intensive \\
\hline Yield of grain $\left[t \cdot h a^{-1}\right]$ & 4.18 & 4.64 & 3.96 & 5.03 \\
\hline Productivity of $\mathbf{N}$ [ $\mathrm{kg}$ grain $\cdot \mathrm{kg}^{-1} \mathbf{N}$ ] & 38.0 & 29.9 & 36.0 & 32.4 \\
\hline Productivity of NPK $\left[\mathrm{kg} \mathrm{grain} \cdot \mathrm{kg}^{-1}\right.$ NPK $]$ & 14.7 & 13.1 & 13.9 & 14.7 \\
\hline The value of production [PLN·ha $\left.{ }^{-1}\right]$ & 5204 & 5776 & 4930 & 6262 \\
\hline Direct costs $\left[\mathrm{PLN} \cdot \mathrm{ha}^{-1}\right]$ & 1927 & 2566 & 1927 & 2566 \\
\hline $\begin{array}{l}\text { Direct surplus without direct payment } \\
{\left[P L N \cdot h a^{-1}\right]}\end{array}$ & 3277 & 3210 & 3003 & 3696 \\
\hline Crop balancing direct costs $[\mathrm{t}]$ & 1.58 & 2.06 & 1.55 & 2.06 \\
\hline $\begin{array}{l}\text { Indicator of direct profitability without direct } \\
\text { payment [ \%] }\end{array}$ & 270 & 225 & 255 & 244 \\
\hline
\end{tabular}

\section{Conclusions}

1) The intensity of the technology applied had an impact on the production and economic effects of spring durum wheat cultivation. Durum wheat cultivated under intensive technology yielded higher than under the average level of agrotechnics. A significant increase in grain yield was observed in the harvest year 2014 , amounting to $1.07 \mathrm{t} \cdot \mathrm{ha}^{-1}$.

2) The level of technology intensity of input costs determined the direct cost structure. Medium-intensive technology without growth retardant, with limited fungicide protection, and a low level of mineral fertilisation turned out to be cheaper.

3) Comparable technologies ensured profitability of durum wheat grain production. The most favourable profitability index was recorded for intensive technology in 2014.

\section{Bibliography}

1. Dropka, D. (2004). Efektywnosc energetyczna zroznicowanej uprawy przedsiewnej na przykladzie pszenzyta ozimego (Energy efficiency of different pre-sowing cultivation on the example of winter triticale), Annales UMCS, Sec. E, 59(4), pp. 2071-2077.

2. Grabinski, J. (2015). Efekty produkcyjne i ekonomiczne intensywnej i integrowanej technologii produkcji pszenicy ozimej i jeczmienia jarego (Productive and economical efects of intensive and integrated technology production of winter wheat and spring barley). Roczniki Naukowe, XVII, pp. 95-99.

3. Harasim, A. (2007). (red) Wybrane elementy technologii produkcji roslinnej. Ksztaltowanie srodowiska rolniczego Polski oraz zrownowazony rozwoj produkcji rolniczej (Selected elements of plant production technology. Shaping the Polish agricultural environment and sustainable development of agricultural production). Studia i Raporty IUNG - PIB Pulawy, 7.

4. IERigZ-PIB. (2018). Rynek rolny. Analizy. Tendencje. Oceny. (Agricultural market. Analysis. Trends. Assessment). Warszawa, IERiGZ-PIB.

5. Jaczewska-Kalicka, A., Krasinski, T. (2010). Czynniki wplywające na wzrost konkurencyjnosci w produkcji zboz. Roczniki Naukowe, 10(4), pp. 130-133. 
6. Jarecki, W., Buczek, J., Bobrecka-Jamro, D. (2013). Wplyw nawozenia azotem na wielkosc plonu ziarna pszenicy twardej (Triticum durum Desf.) (Influence of nitrogen fertilization on yield of durum wheat (Triticum durum Desf.)). Fragmenta Agronomica, 30(2), pp. 68-75.

7. Krasowicz S. (1999). Ekonomiczna ocean plodozmianow zbozowych w roznych warunkach polowych. (Economic assessment of cereal crop rotations in different field conditions). Roczniki Nauk Rolniczych, 88(1), pp. 117-126.

8. Krasowicz, S. (2009). Mozliwosci rozwoju roznych systemow rolniczych w Polsce (The possibilities for development of different agricultural systems in Poland). Roczniki Nauk Rolniczych, G, 96, 4, pp. 110-121.

9. Krasowicz, S., Nowacki, W. (2005). Wplyw intensywnosci produkcji na efektywnosc technologii produkcji roslinnej (The impact of production intensity on the efficiency of plant production technologies). Pamietnik Pulawski, 140, pp. 80-102.

10. Nierobca, P., Grabinski, J., Szelezniak, E. (2008). Wplyw intensywnosci technologii uprawy zboz w plodozmianie zbozowym na efektywnosc produkcyjna i ekonomiczna (The influence of the intensity of cereal cultivation technology in crop rotation on production and economic efficiency). Acta Scientorum Polonorum, Agricultura, 7, 3, pp. 71-80.

11. Nowak, A., Haliniarz, M., Kwiatkowski, C. (2013). Aspekty ekonomiczne wybranych technologii produkcji pszenicy jarej (Economical aspects of selected production technology of spring wheat cultivation). Roczniki Naukowe, XVI, 2, pp. 200-205.

12. Panasiewicz, K., Koziara, W., Sulewska., H. (2011) Produktywnosc azotu w uprawie pszenicy twardej jarej (Triticum durum DESF.) (Productivity of nitrogen fertilization on spring triticum durum (Triticum durum Desf.)). Nauka Przyroda Technologie, 5(2), pp. 1-7.

13. Rachon, L., Szumilo, G. (2002). Plonowanie i jakosc niektorych polskich i zagranicznych odmian linii pszenicy twardej (Triticum durum Desf.). (Yield and grain quality of some Polish and foreign varieties and limes of hard wheat (Triticum durum Desf.)). Pamietnik Pulawski, 130, pp. 77-86.

14. Rachon, L., Szumilo, G. (2006). Plonowanie a oplacalnosc uprawy pszenicy twardej (Triticum durum Desf.) (Yielding and profitability of hard wheat (Triticum durum Desf.)) Pamietnik Pulawski., 142, pp. 404-409.

15. Rachon, L., Szumilo, G., Brodowska, M., Wozniak, A. (2015). Nutritional value and mineral composition of grain of selected wheat species depending on the intensity of a production technology. Journal of Elementology, 20(3), pp. 705-715.

16. Rachon, L., Szumilo, G., Machaj, H. (2014). Wplyw intensywnosci technologii uprawy na plonownie roznych genotypow pszenicy ozimej (Influence of intensity cultivars technology on the yield on different genotype of winter wheat). Annales Universitatis , LXIX (3), pp.32-41.

17. Segit, Z., Szwed-Urbas, K. (2008). Zroznicowanie genetyczne cech uzytkowych pszenicy twardej (Genetic differentiation of some utility traits of spring durum wheat). Biuletyn IHAR, 250, pp. 117-124.

18. Sulek, A., Podolska, G. (2012). Wplyw integrowanej technologii produkcji na plonowanie pszenicy jarej (The influence of production technology on yielding of spring wheat cultivars). Progress in plant Protection. Postępy w Ochronie Roslin. 52(4), pp. 945-950.

19. Sulek, A., Nierobca, P., Podolska, G. (2016). Ocena ekonomiczna technologii produkcji pszenicy ozimej o roznym poziomie intensywnosci (Economic evaluation of winter wheat production technology with different intensity levels). Roczniki Naukowe, XVIII, 2, pp. 256-260.

20.Szmigiel, A., Oleksy, A., Kolodziejczyk, M. 2006. „Porownanie oplacalnosci roznych grup uzytkowych pszenicy ozimej w zaleznosci od poziomu agrotechniki" (Comparison of profitability of grain production of different utilization groups of winter wheat in dependence on agricultural production technology). Pamietnik Pulawski, 142, pp. 525535. 